\title{
Invertebrate drift and colonization processes in a tropical Andean stream
}

\author{
Blanca Ríos-Touma ${ }^{1,2, *}$, Narcís Prat ${ }^{1}$, Andrea C. Encalada ${ }^{2,3}$ \\ ${ }^{1}$ Freshwater Ecology and Management Group, Departament d'Ecologia, Universitat de Barcelona, Av. Diagonal 645, \\ 08028 Barcelona, Spain \\ ${ }^{2}$ Laboratorio de Ecología Acuática, Colegio de Ciencias Biológicas y Ambientales, Universidad San Francisco de Quito, \\ Av. Diego de Robles s/n y Pampite, Cumbayá-Quito, Ecuador \\ ${ }^{3}$ Marine and Environmental Research Center (IMAR-CMA), Department of Life Sciences, Universidade de Coimbra, \\ Coimbra, Portugal
}

\begin{abstract}
We studied invertebrate drift (intensity, propensity, and diel changes) and the recolonization process of stones in a tropical high-altitude stream in Ecuador for a period of 7 to $25 \mathrm{~d}$ during the wet and dry seasons. Our aim was to identify whether seasonal differences in flow produce differences in drift parameters and in the recolonization process, and to examine the role of microhabitat (fast-flow vs. slow-flow areas) in this process. Invertebrate community metrics in drift did not differ between seasons at base flow $\left(<100 \mathrm{l} \mathrm{s}^{-1}\right)$, but they were highly correlated with high flow events. As a result, drift propensity values for several taxa were higher during the wet season, when higher flows occurred, indicating that some taxa suffer catastrophic drift (e.g. Podonominae, Simuliidae). In the short-term experiment, taxa richness, density, and diversity of the colonizers increased with time (up to Day 7). On a longer scale (Days 7 to 25; mid-term experiment), time did not affect community metrics. Microhabitat had strong effects on the composition of colonized stones, and was related to the abundance of taxa in the drift. While some taxa that are scarce in drift were only found in slow-flow areas (e.g. Nectopsyche), suggesting that these species actively search for refuges in the stream, copious species in the drift (e.g. Baetodes) were very abundant on the recolonizing stones, especially during the wet season. The present study suggests that flow, the variability of flow (within and between seasons), and its consequences on the drift of several species play a pivotal role in invertebrate colonization and in the structuring of invertebrate communities in different microhabitats of high-altitude tropical streams.
\end{abstract}

KEY WORDS: Flow disturbance - Colonization - Macroinvertebrates · Drift propensity · Microhabitat $\cdot$ Baetodes $\cdot$ Nectopsyche $\cdot$ Ecuador

\section{INTRODUCTION}

Recolonization of stream substrate after a disturbance is one of the most important processes that structures macroinvertebrate communities in lotic systems (Boyero \& Bosch 2004). This recovery is generally fast (Mackay 1992, Flecker \& Feifarek 1994), beginning within $1 \mathrm{~h}$ of the disturbance (Boyero \& DeLope 2002) and ending in as little as $30 \mathrm{~d}$ (Lake \& Schreiber 1991). Recolonization depends mainly on individuals that arrive with the drift (movement within the water column from upstream), from communities in surrounding patches, and by recruitment through oviposition (Williams \& Hynes 1976, Encalada \& Peckarsky 2006). Many factors affect the colonization process such as substrate characteristics, associated food sources, competition, and predation (Resetarits 1991, Mackay 1992, Resetarits 2001).

Drift composition may profoundly influence benthic community dynamics by either reducing benthic density of the species more prone to drift, which affects the local species composition and abundance, 
or by the continuous settling of animals in the substrate, colonizing downstream areas (Townsend \& Hildrew 1976). The study of drift, which is a recurrent topic of study in stream ecology, has generated a lot of data but few clear conclusions. In temperate areas, where the role of drift in benthic recolonization is well studied and documented (Brittain \& Eikeland 1988, Mackay 1992), it has been established that at small temporal scales a great majority of the colonizing fauna come from drift (Williams \& Hynes 1976), and that drift shows a strong diel periodicity with an increase of drift density at dawn and dusk (Allan 1978, Allan et al. 1986). Although the benthic fauna from nearby undisturbed patches may play an important role in the recolonization process, this process has not received sufficient attention (Lancaster \& Belyea 1997, Townsend et al. 1997).

In tropical areas, recent studies have shown that diel drift patterns are only present on rivers with fish, while the absence of diel patterns has been reported in fishless rivers (Flecker 1992, Pringle \& Ramirez 1998, Jacobsen \& Bojsen 2002). In the tropics, drift is generally aseasonal (Pringle \& Ramirez 1998, Ramirez \& Pringle 2001, Jacobsen \& Bojsen 2002, Rodriguez-Barrios et al. 2007). Under these conditions, the drift density seems to be more dependent on flow, increasing with high flow conditions (Turcotte \& Harper 1982, Benson \& Pearson 1987). Some tropical streams also show increases in drift intensity during the dry season (Ramirez \& Pringle 2001, Rodriguez-Barrios et al. 2007).

The role of drift in the recolonization processes of tropical systems has been recently addressed (Boyero \& DeLope 2002, Boyero \& Bosch 2004, Melo \& Froehlich 2004). These studies have found evidence that recolonization through the movement of invertebrates in tropical rivers varies among riffles but not among sections of the river, and that the type of individuals that recolonize the stones depends on both the surrounding patches at the local scale and the drift coming from upstream riffles and larger sections of the river (Boyero \& Bosch 2004, Melo \& Froehlich 2004). One drawback to these studies is that they have only focused on one season for a short period of time. Therefore, seasonal differences in drift that can cause differences in the recolonization process have not yet been addressed. Different species traits and life-history adaptations of benthic fauna can also influence how and when certain taxa arrive at new or disturbed substrata. The effect of microhabitat hydraulic conditions on the recolonization process is also still unknown.
Despite the ever-increasing body of literature on drift and the recolonization of tropical rivers, Andean streams remain remarkably understudied (Allan et al. 2006, Jacobsen 2008). Streams in the Andean region are characterized by rapid flow changes that are not easily predictable from seasonal variations in precipitation. This high unpredictability of spates can have important effects on catastrophic (when individuals are washed out by the water forces) and behavioral (when individuals actively enter into drift for foraging or predator avoidance) drift as well as on the recolonization process in these streams. In this context, our aim was to describe the seasonal and diel variation in drift for a high-altitude Andean stream, examine the propensity of different taxa to drift, and compare how these propensities differ among the different seasons. Finally, we explored how these factors impact the recolonization of stones.

\section{MATERIALS AND METHODS}

\section{Study area}

We performed the study at the Piburja stream (3300 $\mathrm{m}$ above sea level [a.s.1.]), a first order stream in the Oyacachi River basin (Amazon basin) located in the Cayambe-Coca National Park in Ecuador $\left(0^{\circ} 13^{\prime} \mathrm{S}\right.$, $\left.78^{\circ} 03^{\prime} \mathrm{W}\right)$. Oyacachi basin includes several vegetation types such as páramos and wet montane forest ( 4000 to $1800 \mathrm{~m}$ a.s.l.; in Báez et al. 1999). Total precipitation in the town of Oyacachi is $\sim 1600 \mathrm{~mm}$ per year and the mean annual temperature is $\sim 10^{\circ} \mathrm{C}$. The precipitation is 2 to $3 \times$ greater than the potential evapotranspiration. This makes for very humid conditions year-round (Skov 1999). Pluviometric records for the last $10 \mathrm{yr}$ from nearby localities show lower rainfall during the dry season from December to February (mean: $100 \mathrm{~mm} \mathrm{mo}^{-1}$, dry season) than in the wet season from May to September (mean: $173 \mathrm{~mm}$ $\mathrm{mo}^{-1}$ ). During the study periods at the study site (Rios Touma et al. 2009) monthly rainfall ranged between 32.6 (December) and $294.8 \mathrm{~mm}$ (July).

We studied a pristine $70 \mathrm{~m}$ reach of the stream located at $3300 \mathrm{~m}$ a.s.l. The stream width along this reach ranges from $1.60 \mathrm{~m}$ to $4.0 \mathrm{~m}$. The surrounding vegetation is an evergreen forest with Alnus acuminata trees and a high diversity of Melastomataceae, Asteraceae, and Rosaceae shrubs. The physiochemical parameters of the stream showed seasonal differences (Rios-Touma et al. 2009, 2011) in mean flow (mean: $71.9 \pm 21.0$ and $50.2 \pm 16.1 \mathrm{l} \mathrm{s}^{-1}$, wet and dry seasons, respectively) and mean water velocity 
(mean: $17.0 \pm 3.8$ and $13.4 \pm 2.21 \mathrm{~s}^{-1}$, wet and dry seasons, respectively) both of which were higher during the wet season (Kruskal-Wallis test; $\mathrm{p}<0.05$ ). We performed all surveys and experiments in April and May of 2006 (wet season), and January and February of 2007 (dry season). The stream has a population of introduced non-native rainbow trout, but its densities are presumably low according to local, anecdotal information.

\section{Drift between seasons}

To identify seasonal changes in invertebrate drift and its relationship with flow, we sampled the stream 4 times each season. During the wet season, we sampled twice during spates and twice during low-flow conditions. For the dry season, samples were taken at basal flow levels. To minimize the error related to the presence of differing taxa at different times of day, the low-flow samples from the wet season and the dry season samples were taken at the same hour as the samples taken when spates occurred. Four (dry season) to 6 (wet season) drift nets $(250 \mu \mathrm{m}$ mesh size) blocking the stream (both in width and depth) were placed in the stream for 20 min to $1 \mathrm{~h}$, depending on flow conditions, at each of the 8 sampling sites. The nets were placed in rapids, and blocking the whole stream section (Smock 2006). Each sample was stored separately and preserved in $4 \%$ formalin. All drift density calculations were made according to previously published protocols (Allan \& Russek 1985). To assess the propensity of taxa to drift, we applied the formula: drift density/benthic density (McIntosh et al. 2002) using the mean values of drift density and benthic density for each season. The benthic mean densities were taken from a simultaneous study conducted at the same time along the same reach of stream (Rios-Touma et al. 2011). These samples were taken using a Surber modified sampler $\left(14 \times 14 \mathrm{~cm}^{2}, 250 \mu \mathrm{m}\right.$ mesh size $)$.

\section{Drift periodicity}

To assess whether there is a diel periodicity for invertebrate drift, we collected drift samples 4 times over the course of $24 \mathrm{~h}$ during the dry season (lowflow conditions) as follows: (1) From 10:30 to 13:30 $h$; (2) from $16: 30$ to $19: 30 h_{i}$ (3) from $22: 30$ to $01: 30 h_{\text {; }}$ and (4) from 04:30 to $07: 30 \mathrm{~h}$. We placed 4 nets ( $250 \mu \mathrm{m}$ mesh, $15 \times 35 \mathrm{~cm}$ frame, $2 \mathrm{~m}$ long) in a transect across the river for $3 \mathrm{~h}$ during each of the 4 sam- pling periods. Water flow and average velocity for each net mouth was measured at the beginning, middle, and end of each sampling period. Each drift sample was stored separately and preserved in $4 \%$ formalin.

\section{Colonization of benthic substrate}

We assessed the invertebrate short term colonization of stones in Piburja stream by performing a $7 \mathrm{~d}$ colonization experiment during the dry season (basal flow conditions). On the first day, we placed 24 cleaned cobble stones of similar size (mean area $=$ $0.014 \mathrm{~m}^{2}$ ) and smoothness in the stream. We marked the stones with white paint to recognize them, and to measure how they turned and rolled. We used stones because they are considered well-defined and discrete habitats within a stream (Douglas \& Lake 1994), appropriate for colonization studies (Boulton et al. 1988). Twelve stones were placed in fast-velocity areas (rapids) and 12 were placed in slow-velocity areas (potential refugia). Fast-velocity patch zones are significantly faster (wet season $v=0.53$ var $0.09 \mathrm{~m} \mathrm{~s}^{-1}$; dry season $v=0.50$ var $0.04 \mathrm{~m} \mathrm{~s}^{-1}$ ) than slow-velocity patches (wet season $v=0.06$ var $0.00 \mathrm{~m}$ $\mathrm{s}^{-1}$; dry season $\mathrm{v}=0.02$ var $0.00 \mathrm{~m} \mathrm{~s}^{-1}$ ) (values from Rios-Touma 2008). Four cobbles from the rapids and 4 from the refugia were inspected for the presence of invertebrates by placing a $250 \mu \mathrm{m}$ mesh hand net downstream at 1,3 , and $7 \mathrm{~d}$ after the beginning of the experiment. The surrounding velocity and stone area (maximum length $\times$ maximum width) were measured for each stone. Stone turning was recorded based on 5 categories: (1) no change; (2) less than $45^{\circ}$ of inclination; (3) between 45 and $135^{\circ}$; (4) close to $180^{\circ}$; and (5) upside down. This process was repeated 3 times during the dry season along the same reach of stream. During the experiment, the stones did not move downstream. The invertebrates collected from the rocks were preserved in $4 \%$ formalin and taken to the laboratory for sorting and identification.

In a second experiment, we tested invertebrate recolonization dynamics on a longer time scale (midterm experiment). Marked clean and dry cobbles (mean area: $0.015 \mathrm{~m}^{2}$ ) were placed in fast-flow and slow-flow patches along the entire reach of stream (45 cobbles in the wet season and 60 in the dry season). Stones from both patches were collected 4 times each season (at 7, 12-14, 17-19, and 22-25 d after the stones were placed on the river). Similar to the short-term colonization study, for each date we recorded the surrounding velocity around each stone 
together with the stone area (maximum length $\times$ maximum width), and evaluated stone turning. The invertebrate samples were also collected in a fashion similar to that of the short-term experiment. The invertebrates from all drift and colonization samples were classified up to the genus level when possible; Chironomids were classified to the sub-family level, and Oligochaeta, Nematomorpha, and Tricladida were classified to the order level.

\section{Data analyses}

Invertebrate taxa densities were $\log (x+1)$ transformed when necessary to satisfy homogeneity of variance assumptions necessary to perform the statistical test explained below. In addition to taxa densities, we calculated 4 community metrics for each experiment: richness $(S)$, total density $(N)$, Fisher's $\alpha$, and Shannon-Wiener $\left(H^{\prime}\right)$ index as log base e.

\section{Drift between seasons}

We predicted that catastrophic or behavioral drift densities would increase with flow due to invertebrates getting dislodged during spates, or as a consequence of different hydrological conditions between the 2 seasons. To test this, drift community metrics from the seasonal drift survey were related to flow measurements using Spearman's rank correlations. To assess seasonal changes in the composition of drift, we applied the non-metric multidimensional scaling using Bray-Curtis similarities with the $\log (x+1)$ transformed drift densities and ANOSIM analysis to test significant differences among seasons.

\section{Drift periodicity}

We hypothesized that at dawn and dusk, all community metrics and taxa densities would be increased compared to the other periods of the day. To test for differences in the community metrics between drift samples from the 4 time intervals, we used a 1-way ANOVA, where the factor was the period of the day that was at 4 levels: morning (10:30 to 13:30 h); evening including dusk (16:30 to 19:30 h); night (22:30 to $01: 30 \mathrm{~h}$ ); and morning including dawn (04:30 to 07:30 h). There were 4 replicates for each period. Since taxa density for most taxa was not normally distributed, we tested drift taxa densities from these 4 intervals by applying a Kruskal-Wallis ANOVA.

\section{Colonization of benthic substrate}

For the short-term colonization experiment, we predicted that invertebrate colonization would be influenced by the time since stone placement (colonization days), stone movement, and the flow-velocity patch where the stone was located. To analyze the effect of these factors, we performed the KruskalWallis ANOVA to assess differences in community metrics and taxa densities. We chose this analysis since the data were not normally distributed after transformation.

For the mid-term colonization experiment, we hypothesized that the season would have an effect on the dynamics of the colonizing fauna. To test this hypothesis, we performed a 3-way ANOVA with the different community metrics as response variables along with 3 factors: season (2 levels: wet and dry); colonization time (4 levels: $7,12-14,17-19$, and 22-25 d); and velocity patches (2 levels: fast and slow). A Tukey's post-hoc comparison was used to determine significant pair-wise differences among factors when significant. For taxa density (for different families or genera), we tested seasonal differences within microhabitat and the number of colonization days, using a Kruskal-Wallis ANOVA. The false discovery rate correction (FDR; Benjamini \& Hochberg 1995) of $\mathrm{p}$ values was applied to all multiple tests. The analyses were performed using Statistica 6 and Primer 6 statistical software.

\section{RESULTS}

\section{Differences in seasonal drift}

Although community metrics (richness, total drift density, and Shannon-Wiener and Fisher's $\alpha$ indexes) did not show any significant variation between the seasons (Table 1), richness and Fisher's $\alpha$ were highly correlated with flow (Rho Spearman's rank correlation: $0.76 ; p=0.031$ and $0.83 ; p=0.010$, respectively). This was corroborated by the nonmetric multidimensional scaling (NMDS) (Fig. 1) and ANOSIM analyses (global $\mathrm{R}=0.521, \mathrm{p}=0.29$ ) that showed no association of any invertebrate metrics with season. In general, drift propensity values were higher during the wet season than the dry season (Fig. 2, Appendix 1) for several taxa that were present in both seasons (Fig. 2, Appendix 1). This was especially true for Podonominae, Diamesinae, Muscidae, Hydracarina, Ochotrichia, Simuliidae, Pyralidae, and Planorbiidae that presented 
Table 1. Mean values of community metrics of macroinvertebrate drift and summary of ANOVA for seasonal differences among these metrics at Piburja stream, Oyacachi basin, Ecuador. dfs are error and factor values

\begin{tabular}{|lccccc|}
\hline Community metrics & Mean wet & Mean dry & df & $F$ & $\mathrm{p}$ \\
\hline Richness $(S)$ & $27.75 \pm 8.22$ & $26.00 \pm 6.98$ & $6 ; 1$ & 0.105 & 0.756 \\
Total drift density $(N)$ & $600.48 \pm 169.65$ & $596.35 \pm 201.91$ & $6 ; 1$ & 0.001 & 0.976 \\
Fisher's $\alpha$ & $6.30 \pm 2.34$ & $5.67 \pm 1.38$ & $6 ; 1$ & 0.214 & 0.660 \\
$H^{\prime}\left(\log _{\mathrm{e}}\right)$ & $2.19 \pm 0.21$ & $2.29 \pm 0.27$ & $6 ; 1$ & 0.331 & 0.586 \\
\hline
\end{tabular}

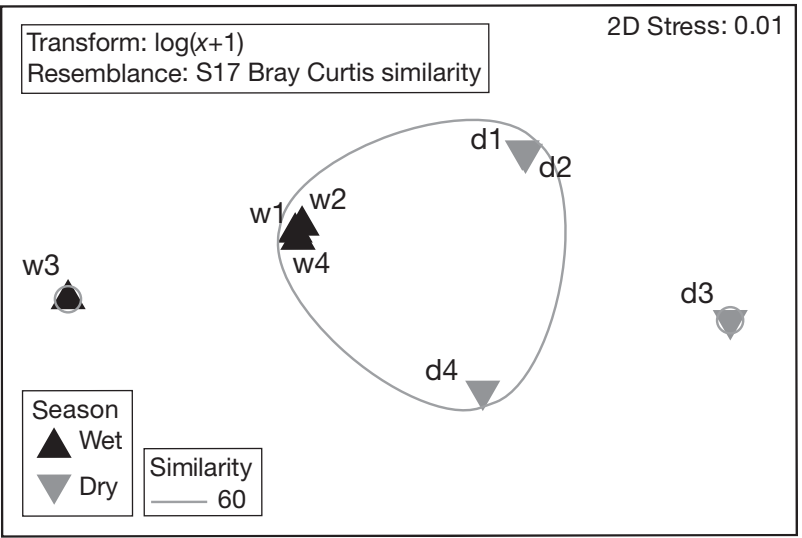

Fig. 1. Non-metric multidimensional scaling of the 4 drift samples taken in the dry and wet seasons. Each triangle is the average of the 4 to 6 replicates of each sampling date at Piburja stream. Average similarity at $60 \%$ did not show different groups per season

higher drift propensity values during the wet season. Stratiomydae, Maurinia, and Tipula were the only taxa that presented more drift propensity during the dry season, although the absolute values for all these parameters were very low. In the dry season, all taxa had low drift propensity values (Fig. 2, Appendix 1).

\section{Composition of benthos compared to drift at both seasons}

When comparing the composition of benthos and drift samples, we found that in the wet season, 17 of the 52 taxa present in drift samples were absent from the benthos samples, and Tricladia and Hirudinea were only present in benthos Surber samples. In the dry season, 28 taxa were found in the drift and 50 were found in the benthos Surber samples (Table 2, Appendix 1). Orthocladiinae and Nectopsyche were the most common taxa (up to $>30 \%$ of the abundance) in both the benthos and drift, while Simuliidae, which was abundant in drift $(13 \%)$, represented only $3 \%$ of the individuals in the benthos Surber samples. Other taxa such as Ceratopogonidae (8\%) and Elmidae (5\%) were abundant in the benthos Surber samples, but were less important or almost absent in drift samples. During the wet season, Orthocladiinae and Baetodes were the dominant taxa in the benthos (almost $50 \%$ combined) and drift ( $>40 \%$ combined; Table 2 ). Some taxa were only abundant in the drift samples (Hydracarina, Simuliidae, and Ochotrichia), while other taxa were only abundant in Surber samples (Chironominae and Ceratopogonidae). The principal difference between the 2 seasons was that Baetodes was one of the dominant taxa in the wet season, which was much less abundant during the dry season. In the same way, Nectopsyche was dominant during the dry season, but became less important in the wet season. Interestingly, Podonominae presented higher densities in drift samples for the wet season but had higher abundances in benthos samples during the dry season. As stated previously (Fig. 2), Podonominae

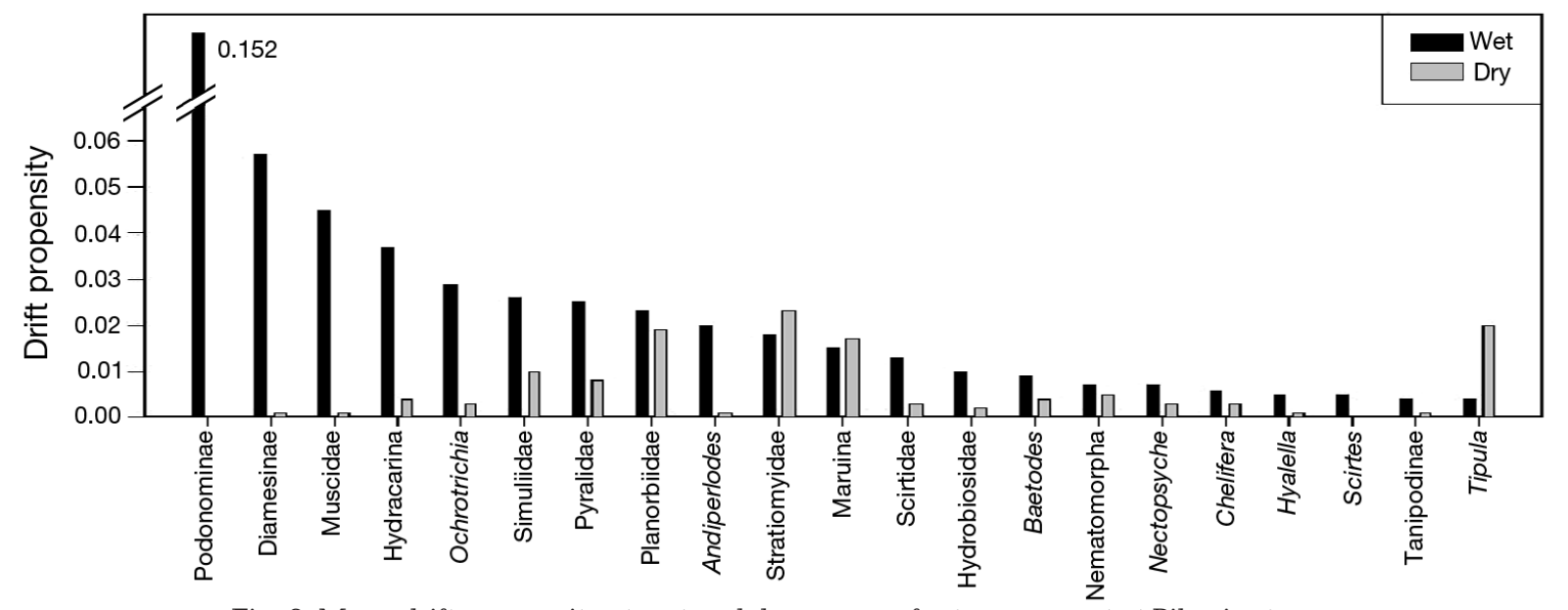

Fig. 2. Mean drift propensity at wet and dry seasons for taxa present at Piburja stream 
has the highest propensity to enter the drift during the wet season.

\section{Drift diel periodicity}

At the community level, we did not find significant differences in community metrics for different periods of the day (Table 3). Total density, richness, Fisher's $\alpha$, and Shannon-Wiener indexes did not differ among time periods, and the slight rise detected at dusk was not significant. We also performed this analysis using the rarefied data, and once again, we did not detect significant differences between time periods. From the 28 taxa that were common on drift samples in the diel experiment, only the ephemeropterans Baetodes and Leptohyphes showed significant differences between periods (Fig. 3) according to the Kruskal-Wallis ANOVA (Table 4). Higher drift densities were found in the period that included dusk (between 17:30 and 19:30 h), but there was a large variability between replicates.

\section{Colonization of benthic substrate}

\author{
Short-term colonization of stones at basal flow \\ conditions
}

In the three $7 \mathrm{~d}$ colonization experiments (performed only in the dry season, and under base flow conditions), a total of 42 taxa were found. Of these 27 were found after the first day of colonization; 30 were found after $3 \mathrm{~d}$; and 38 were found after $7 \mathrm{~d}$. From these 42 taxa, 8 arrived at the end of the colonization experiment, and only 1 (Tricladia) was present on the first day and disappeared in the following days. According to the Kruskal-Wallis ANOVA (Table 5), there was a higher invertebrate density and richness on Day 7 than on any other day. Additionally, densities of Chironominae, Orthocladiinae, Tanytarsini, and Leptohyphes were significantly higher on Day 7 (Table 5). As expected, more differences were detected between Days 1 and 7 than between Days 1 and 3. Richness, total density, and Fisher's $\alpha$ diversity were significantly higher

Table 2. Macroinvertebrate dominance (as \% of total density) of drift, Surber, and stone samples at Piburja stream during wet and dry seasons. Only taxa representing more than $1 \%$ of total density were included. Taxa are ordered according to dominance in drift in the wet season

\begin{tabular}{|c|c|c|c|c|c|c|c|c|}
\hline \multirow{3}{*}{ Taxon } & \multirow{3}{*}{$\overline{\text { Drift }}$} & \multirow{3}{*}{ Surber } & \multicolumn{2}{|c|}{ - Wet } & \multirow{3}{*}{ Drift } & \multirow{3}{*}{ Surber } & \multirow{2}{*}{\multicolumn{2}{|c|}{ Dry }} \\
\hline & & & & ones & & & & \\
\hline & & & Fast velocity & Slow velocity & & & Fast velocity & Slow velocity \\
\hline Orthocladiinae & 20.30 & 36.59 & 18.04 & 46.81 & 21.88 & 20.00 & 18.51 & 18.47 \\
\hline Baetodes & 19.75 & 12.92 & 30.69 & 7.76 & 2.99 & 2.01 & 7.17 & 7.17 \\
\hline Simuliidae & 10.22 & 2.44 & 20.80 & 0.64 & 12.75 & 3.35 & 17.15 & 5.40 \\
\hline Hydracarina & 9.93 & 1.63 & 0.42 & 6.64 & 8.44 & 5.93 & 4.4 & 6.11 \\
\hline Ochrotrichia & 5.15 & 1.08 & 2.39 & 2.97 & 4.47 & 3.60 & 4.06 & 2.74 \\
\hline Podonominae & 4.47 & 0.18 & 0.82 & 0.87 & 0.09 & 0.62 & 0.15 & 2.35 \\
\hline Nectopsyche & 4.43 & 4.16 & 7.18 & 15.87 & 12.95 & 11.31 & 11.04 & 23.92 \\
\hline Chironominae & 3.76 & 11.02 & 0.82 & - & 6.35 & 7.19 & 5.68 & 5.19 \\
\hline Tanypodinae & 1.88 & 2.62 & 4.67 & 3.29 & 0.37 & 0.84 & 0.13 & - \\
\hline Chelifera & 1.63 & 1.72 & 2.05 & 1.05 & 2.27 & 1.81 & 0.98 & 0.37 \\
\hline Stratiomyidae & 1.60 & 0.54 & - & - & 2.89 & 0.35 & 0.14 & 0.29 \\
\hline Tanytarsini & 1.30 & 2.26 & - & - & 1.15 & 3.35 & 9.02 & 7.16 \\
\hline Ceratopogonidae & 1.13 & 6.41 & 0.39 & - & 2.61 & 8.41 & 0.95 & 2.18 \\
\hline Maruina & 1.12 & 0.45 & - & - & 3.14 & 0.50 & 0.3 & 0.21 \\
\hline Muscidae & 1.07 & 0.15 & - & - & 0.04 & 0.11 & - & - \\
\hline Planorbiidae & 1.02 & 0.27 & - & - & 0.88 & 0.12 & - & - \\
\hline Total Scirtidae & 0.93 & 0.45 & 0.55 & - & 1.01 & 0.89 & - & 0.43 \\
\hline Hydrobiosidae & 0.88 & 0.54 & 4.09 & 0.71 & 0.73 & 1.27 & 2.55 & 0.52 \\
\hline Blephariceridae & 0.85 & - & 0.42 & - & 0.72 & 0.09 & - & - \\
\hline Diamesinae & 0.83 & 0.09 & - & - & 1.19 & 2.78 & 1.5 & 0.47 \\
\hline Oligochaeta & 0.79 & 4.25 & 0.87 & 2.39 & 2.28 & 4.24 & 2.36 & 1.56 \\
\hline Tipula & 0.64 & 0.90 & - & - & 2.75 & 0.37 & 0.14 & - \\
\hline Total Elmidae & 0.61 & 2.08 & - & - & 0.20 & 5.28 & 1.79 & 0.46 \\
\hline Leptohyphes & 0.58 & 1.26 & 1.68 & 1.33 & 0.10 & 4.17 & 6.01 & 5.47 \\
\hline Limonidae & 0.55 & - & - & - & 1.78 & 0.47 & 0.72 & 0.35 \\
\hline Cochliopsyche & 0.29 & 0.63 & 1.50 & 4.12 & 0.32 & 1.74 & 1.47 & 3.55 \\
\hline Gripopterygidae gen. A & 0.29 & 0.09 & 0.82 & 2.01 & 0.55 & 1.01 & 1.18 & 1.30 \\
\hline
\end{tabular}


Table 3. Summary of the 1-way ANOVA of community metrics measured during the diel experiment at Piburja stream. The factor time has 4 time intervals: morning (10:30 to $13: 30 \mathrm{~h})$; evening, including dusk (16:30 to 19:30 h); night (22:30 to $01: 30 \mathrm{~h})$, and dawn (04:30 to $07: 30 \mathrm{~h})$

\begin{tabular}{|c|c|c|c|c|c|c|}
\hline & & SS & df & MS & $F$ ratio & $\mathrm{p}$ \\
\hline \multirow{3}{*}{ Total density $(N)$} & Inter-groups & 2.323 & 3 & 0.774 & \multirow[t]{3}{*}{1.0694} & \multirow[t]{3}{*}{0.3986} \\
\hline & Intra-groups & 8.690 & 12 & 0.724 & & \\
\hline & Total & 11.014 & 15 & & & \\
\hline \multirow[t]{3}{*}{ Richness $(S)$} & Inter-groups & 78.750 & 3 & 26.250 & \multirow[t]{3}{*}{0.3702} & \multirow[t]{3}{*}{0.7760} \\
\hline & Intra-groups & 851.000 & 12 & 70.917 & & \\
\hline & Total & 929.750 & 15 & & & \\
\hline \multirow[t]{3}{*}{ Fisher's $\alpha$} & Inter-groups & 3.592 & 3 & 1.197 & \multirow[t]{3}{*}{0.2127} & \multirow[t]{3}{*}{0.8857} \\
\hline & Intra-groups & 67.557 & 12 & 5.630 & & \\
\hline & Total & 71.149 & 15 & & & \\
\hline \multirow[t]{3}{*}{$H^{\prime}\left(\log _{\mathrm{e}}\right)$} & Inter-groups & 0.648 & 3 & 0.216 & \multirow[t]{3}{*}{0.3924} & \multirow[t]{3}{*}{0.7607} \\
\hline & Intra-groups & 6.606 & 12 & 0.550 & & \\
\hline & Total & 7.254 & 15 & & & \\
\hline
\end{tabular}

days, and microhabitat (Table 6) for each season. Of all the taxa analyzed, only Orthocladiinae showed a significant relationship with colonization days (Kruskal-Wallis test; Appendix 2), with higher densities at Days 14 and 25 in the dry season. No relationship was found between colonization days and the density of different taxa during the dry season. The relationship between taxa density and colonization days was weak in the wet season, and, again, only Orthocladiinae showed a significant increase at Day 17 (Kruskal-Wallis test; Appendix 2). However, community metrics clearly differed among the microhabitat types (Table 6), with a in rocks located in rapids than those in refugia areas (Table 5). The densities of Simuliidae, Baetodes, and Hydrobiosidae were higher in the rapids, whereas only Cocliopsyche had a higher density in slow-flow areas.

No movement of stones was detected during the experiment, although some of them did turn in place. Stone turning was important for Podonominae and Hydrobiosidae. Both showed a significant reduction in density when the stones rolled or turned at least $180^{\circ}$. Even though this reduction by stone movement in these 2 taxa, there was no effect of stone movement on the community metrics.

Mid-term recolonization of stone fauna: effect of local hydrological conditions and seasons

Data from this experiment came from the marked cobbles located in fast-velocity and slow-velocity areas of the stream during the dry and wet seasons. They were sampled from $7 \mathrm{~d}$ up to $25 \mathrm{~d}$ at 5 to $7 \mathrm{~d}$ intervals. From the 41 taxa registered for both seasons, few taxa showed significant seasonal changes (Kruskal-Wallis ANOVA; Appendix 2). Chironominae, Tanytarsini, and Leptohyphes were significantly more abundant during the dry season, and Tanypodinae was more abundant in the wet season.

Community metrics did not differ between days (from Day 7 to Day 25). We did not find significant differences between the community metrics using a 3-way ANOVA performed with season, colonization
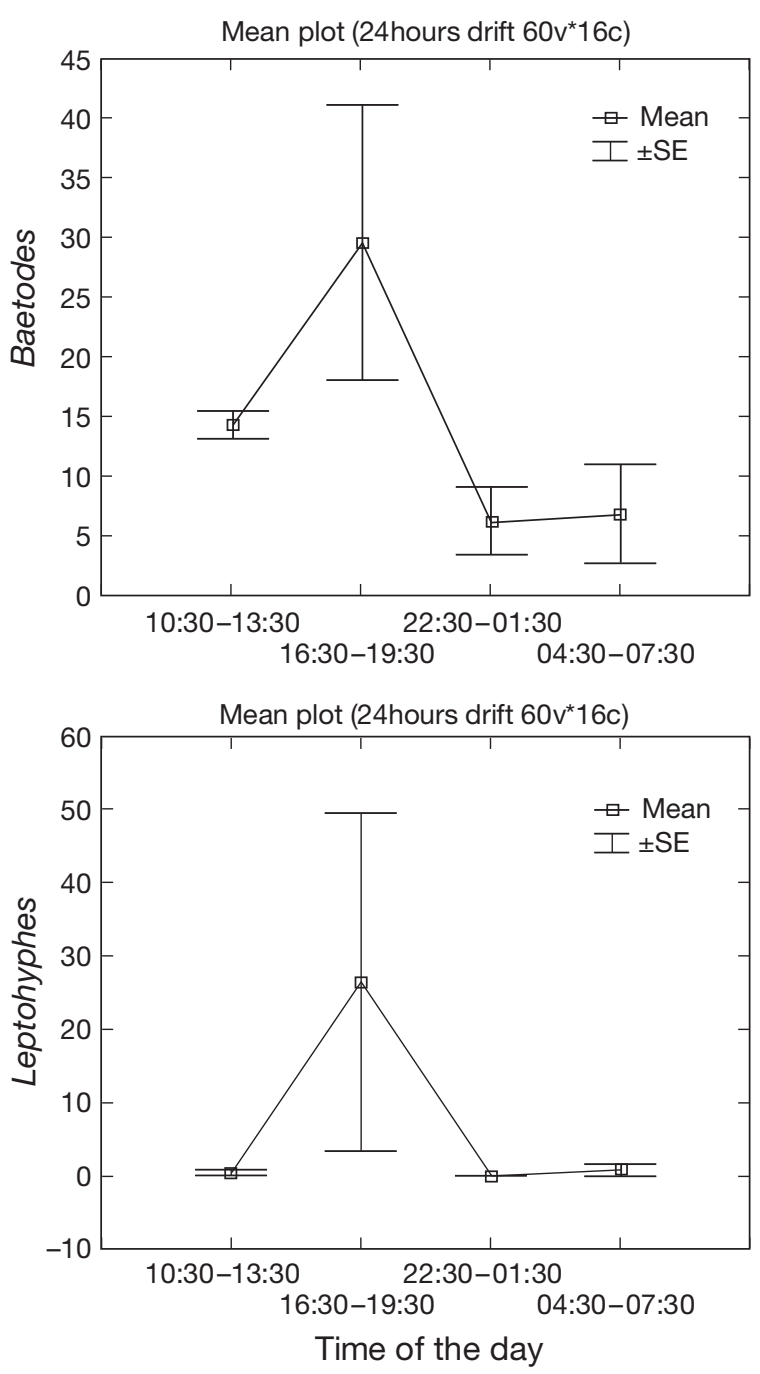

Fig. 3. Diel changes in Baetodes and Leptohyphes drift density (ind. $100 \mathrm{~m}^{-3}$ ) at base flow conditions at Piburja stream. Mean values; scale bars are $\pm 1 \mathrm{SE}$ 
Table 4. Kruskal-Wallis test for macroinvertebrate drift densities (ind. $100 \mathrm{~m}^{-3}$ ) at the 4 sampling periods during $1 \mathrm{~d}$ (diel drift). Significant values of $\mathrm{p}$ after False Discovery Rate (FDR) correction are indicated in bold

\begin{tabular}{|c|c|c|c|c|c|c|c|}
\hline \multirow[t]{2}{*}{ Taxon } & \multicolumn{3}{|c|}{ Kruskal-Wallis test } & \multicolumn{4}{|c|}{ Mean drift density at each time of the day } \\
\hline & $\chi^{2}$ & $\mathrm{df}$ & $\mathrm{p}$ & $10: 30-13: 30$ & $16: 30-19: 30$ & $22: 30-01: 30$ & $04: 30-07: 30$ \\
\hline Leptohyphes & 10.711 & 3 & 0.013 & 0.386 & 26.469 & 0.000 & 0.824 \\
\hline Baetodes & 9.075 & 3 & 0.028 & 14.372 & 29.647 & 6.329 & 6.895 \\
\hline Chironominae & 6.790 & 3 & 0.079 & 4.919 & 43.211 & 17.453 & 6.895 \\
\hline Ochrotrichia & 5.481 & 3 & 0.140 & 11.210 & 17.579 & 3.237 & 6.189 \\
\hline Nectopsyche & 5.412 & 3 & 0.144 & 19.188 & 65.013 & 30.973 & 27.641 \\
\hline Oligochaeta & 5.186 & 3 & 0.159 & 2.718 & 36.495 & 2.487 & 1.799 \\
\hline Simuliidae & 5.009 & 3 & 0.171 & 54.730 & 100.768 & 44.617 & 46.970 \\
\hline Gripopterygidae gen. A & 4.604 & 3 & 0.203 & 0.000 & 8.545 & 0.000 & 0.412 \\
\hline Contulma & 4.420 & 3 & 0.220 & 0.000 & 8.859 & 1.849 & 0.824 \\
\hline Stratiomyidae & 3.918 & 3 & 0.270 & 7.679 & 1.440 & 2.487 & 4.141 \\
\hline Scritidae gen. B & 3.616 & 3 & 0.306 & 0.000 & 1.042 & 4.264 & 3.349 \\
\hline Tanytarsini & 3.363 & 3 & 0.339 & 18.553 & 61.584 & 16.742 & 21.051 \\
\hline Tipula & 3.169 & 3 & 0.366 & 2.718 & 9.108 & 0.781 & 1.106 \\
\hline Orthocladiinae & 2.934 & 3 & 0.402 & 51.737 & 72.468 & 29.932 & 45.165 \\
\hline Hydracarina & 2.596 & 3 & 0.458 & 39.337 & 43.205 & 22.578 & 31.394 \\
\hline Atopsyche & 2.120 & 3 & 0.548 & 1.158 & 9.504 & 1.244 & 1.583 \\
\hline Staphylinidae & 2.121 & 3 & 0.548 & 5.167 & 12.655 & 5.264 & 9.983 \\
\hline Blepharoceridae & 1.775 & 3 & 0.620 & 7.120 & 29.828 & 7.255 & 15.425 \\
\hline Clognia & 1.473 & 3 & 0.688 & 3.514 & 2.233 & 0.318 & 2.937 \\
\hline Lampirydae & 1.420 & 3 & 0.701 & 2.160 & 0.438 & 1.244 & 3.415 \\
\hline Diamesinae & 1.403 & 3 & 0.705 & 2.857 & 2.127 & 0.636 & 3.349 \\
\hline Psychodidae & 1.370 & 3 & 0.713 & 5.115 & 3.110 & 0.781 & 3.631 \\
\hline Atrichopogon & 1.274 & 3 & 0.735 & 3.393 & 0.479 & 2.054 & 1.387 \\
\hline Elodes & 0.773 & 3 & 0.856 & 2.201 & 1.356 & 2.917 & 6.633 \\
\hline
\end{tabular}

Table 5. Kruskal-Wallis ANOVA for community metrics and taxa densities (rare taxa excluded) between colonization days $(1,3$, or $7 \mathrm{~d})$, stone-movement (from 1 to 5 , in order of increase movement), and microhabitat (fast- vs. slow-current areas). Significant values of $\mathrm{p}$ after FDR correction are indicated in bold

\begin{tabular}{|c|c|c|c|c|c|c|c|c|c|}
\hline \multirow[t]{2}{*}{ Taxon } & \multicolumn{3}{|c|}{ Colonization days } & \multicolumn{3}{|c|}{ Stone movement } & \multicolumn{3}{|c|}{ Microhabitat } \\
\hline & $\chi^{2}$ & $\mathrm{df}$ & $\mathrm{p}$ & $\chi^{2}$ & $\mathrm{df}$ & $\mathrm{p}$ & $\chi^{2}$ & $\mathrm{df}$ & $\mathrm{p}$ \\
\hline Richness $(S)$ & 8.045 & 2 & 0.018 & 6.924 & 4 & 0.140 & 7.161 & 1 & 0.007 \\
\hline Total density $(N)$ & 9.67 & 2 & 0.008 & 4.501 & 4 & 0.342 & 7.928 & 1 & 0.005 \\
\hline Fisher's $\alpha$ & 6.976 & 2 & 0.031 & 8.295 & 4 & 0.081 & 6.479 & 1 & 0.011 \\
\hline$H^{\prime}\left(\log _{\mathrm{e}}\right)$ & 5.285 & 2 & 0.071 & 7.304 & 4 & 0.121 & 3.394 & 1 & 0.065 \\
\hline Elmidae & 0.318 & 2 & 0.853 & 0.929 & 4 & 0.920 & 1.348 & 1 & 0.246 \\
\hline Prionocyphon & 1.134 & 2 & 0.567 & 5.118 & 4 & 0.275 & 0.001 & 1 & 0.972 \\
\hline Chironominae & 10.125 & 2 & 0.006 & 3.564 & 4 & 0.468 & 2.816 & 1 & 0.093 \\
\hline Orthocladiinae & 22.023 & 2 & 0.000 & 6.965 & 4 & 0.138 & 1.697 & 1 & 0.193 \\
\hline Podonominae & 3.932 & 2 & 0.140 & 17.872 & 4 & 0.001 & 3.717 & 1 & 0.054 \\
\hline Tanytarsini & 7.507 & 2 & 0.023 & 2.230 & 4 & 0.693 & 2.131 & 1 & 0.144 \\
\hline Chelifera & 6.788 & 2 & 0.034 & 1.169 & 4 & 0.883 & 4.653 & 1 & 0.031 \\
\hline Limonidae & 2.062 & 2 & 0.357 & 9.555 & 4 & 0.049 & 1.162 & 1 & 0.281 \\
\hline Maruina & 2.086 & 2 & 0.352 & 10.605 & 4 & 0.031 & 1.072 & 1 & 0.300 \\
\hline Psychodidae & 1.046 & 2 & 0.593 & 6.232 & 4 & 0.182 & 0.715 & 1 & 0.398 \\
\hline Simuliidae & 0.001 & 2 & 0.999 & 8.175 & 4 & 0.085 & 33.497 & 1 & 0.000 \\
\hline Stratiomyidae & 5.111 & 2 & 0.078 & 3.632 & 4 & 0.458 & 0.923 & 1 & 0.337 \\
\hline Baetodes & 0.813 & 2 & 0.666 & 5.440 & 4 & 0.245 & 30.593 & 1 & 0.000 \\
\hline Leptohyphes & 10.399 & 2 & 0.006 & 7.804 & 4 & 0.099 & 3.132 & 1 & 0.077 \\
\hline Hydracarina & 1.755 & 2 & 0.416 & 5.467 & 4 & 0.243 & 0.020 & 1 & 0.887 \\
\hline Oligochaeta & 0.938 & 2 & 0.626 & 8.182 & 4 & 0.085 & 0.011 & 1 & 0.918 \\
\hline Contulma & 5.178 & 2 & 0.075 & 3.586 & 4 & 0.465 & 0.002 & 1 & 0.967 \\
\hline Cochliopsyche & 4.171 & 2 & 0.124 & 1.278 & 4 & 0.865 & 7.737 & 1 & 0.005 \\
\hline Hydrobiosidae & 3.903 & 2 & 0.142 & 14.010 & 4 & 0.007 & 10.863 & 1 & 0.001 \\
\hline Hydroptilidae & 0.832 & 2 & 0.660 & 2.398 & 4 & 0.663 & 3.350 & 1 & 0.067 \\
\hline Nectopsyche & 3.244 & 2 & 0.198 & 1.691 & 4 & 0.792 & 3.683 & 1 & 0.055 \\
\hline
\end{tabular}


Table 6. Summary of the 3-way ANOVA of community metrics related to days of permanence of the stone on the river (7 to 25), season (wet vs. dry), and microhabitat (rapids vs. slow-flow areas). Significant values of p after FDR correction are indicated in bold

\begin{tabular}{|c|c|c|c|c|c|c|c|c|c|}
\hline & \multirow[b]{2}{*}{$\mathrm{df}$} & \multicolumn{2}{|c|}{ Shannon-Wiener } & \multicolumn{2}{|c|}{ Fisher } & \multicolumn{2}{|c|}{ Density } & \multicolumn{2}{|c|}{ Richness } \\
\hline & & $F$ & $\mathrm{p}$ & $\mathrm{F}$ & $\mathrm{p}$ & $\mathrm{F}$ & $\mathrm{p}$ & $\mathrm{F}$ & $\mathrm{p}$ \\
\hline Intercept & 1 & 642.821 & 0.000 & 333.308 & 0.000 & 78.365 & 0.000 & 329.078 & 0.000 \\
\hline Colonization days & 3 & 1.655 & 0.185 & 1.444 & 0.238 & 3.609 & 0.018 & 2.169 & 0.100 \\
\hline Season & 1 & 2.890 & 0.094 & 7.639 & 0.007 & 0.359 & 0.551 & 4.791 & 0.032 \\
\hline Microhabitat & 1 & 11.748 & 0.001 & 8.309 & 0.005 & 8.843 & 0.004 & 14.043 & 0.000 \\
\hline Colonization days $\times$ season & 3 & 0.443 & 0.723 & 0.585 & 0.627 & 0.167 & 0.918 & 0.969 & 0.413 \\
\hline Colonization days $\times$ microhabitat & 3 & 0.376 & 0.771 & 0.084 & 0.968 & 0.560 & 0.643 & 0.140 & 0.936 \\
\hline Season $\times$ microhabitat & 1 & 7.507 & 0.008 & 2.047 & 0.157 & 1.898 & 0.173 & 1.374 & 0.245 \\
\hline Colonization days $\times$ season $\times$ microhabitat & 3 & 1.223 & 0.308 & 0.867 & 0.463 & 0.934 & 0.430 & 0.972 & 0.411 \\
\hline Error & 66 & & & & & & & & \\
\hline
\end{tabular}

higher richness, density, and diversity at stones located in rapid areas, independent of colonization days and season (Tukey's post-hoc comparisons). The taxa that showed significant microhabitat preference were more abundant in rapid areas (Kruskal-Wallis analysis; Appendix 2).

We found that during the dry season, 39 taxa were found on the stones (Table 4). Of these, 35 were present on rapid stones, and 31 were present on slow-flow stones. Several taxa showed significant differences between microhabitats (Appendix 2). Nectopsyche represented $24 \%$ of the density of taxa present in slow-flow areas, and Simuliidae made up $17 \%$ of the taxa density on stones located in the rapids (Table 2). For the comparison of taxa found on stones with Surber (Ríos-Touma et al. 2011) and drift samples, Orthocladiinae and Nectopsyche had a similar percentage of total density in both drift and benthos Surber samples. In the low-flow season, there was a marked decrease of Baetodes in both drift and benthos samples, but this taxon still represented an important part of the stone fauna ( $7 \%$ of the density of both refugia and rapid stones). In the wet season, densities of Tanypodinae, Simuliidae, and Baetodes increased in the rapids (Appendix 2). More than $50 \%$ of the density in the rapids was from Baetodes and Simuliidae, while almost $47 \%$ of density in slow-velocity areas was from Orthocladiinae followed by Nectopsyche (16\%). In drift and benthos Surber samples, Orthocladiinae and Baetodes were the dominant taxa. One interesting fact is that in terms of percentage of abundance, $\mathrm{Nec}$ topsyche was less important in drift and benthos Surber samples, although this taxon presents the highest percentages of density on stones located in slow-velocity areas.

\section{DISCUSSION}

In the present study, community metrics in drift did not change between seasons. This was in accordance with previous studies in tropical areas (Turcotte \& Harper 1982, Ramirez \& Pringle 2001, RodriguezBarrios et al. 2007). Unlike Rodriguez-Barrios et al. (2007) and Ramirez \& Pringle (2001), though, we found an increase, not a decrease, in drift richness and diversity in higher flow conditions, a pattern reported previously by Turcotte \& Harper (1982). Drift propensity clearly differs between seasons, so behavioral and catastrophic drift could be differentiated since a great majority of taxa showed high drift propensity values during the wet season. All these taxa, except for Pyralidae, had higher benthic densities in the dry season and higher drift densities during the wet season. Among the dominant taxa present in both drift and benthos samples, only Simuliidae and Hydracarina seemed to suffer catastrophic drift during the wet season, presenting high drift propensity values for the wet season. On the other hand, the large differences in drift propensity values for taxa between seasons suggest that the high values observed in the wet season are result of a continuous dislodgement of the benthic community, and therefore, this can be interpreted as a catastrophic drift. However, dominant taxa, such as Nectopsyche and Baetodes, that had similar drift propensity values between seasons showed seasonality for benthic Surber densities, indicating that catastrophic drift is not related to the changes in abundance between seasons. This is interesting in terms of the strategies used by these taxa to maintain their populations and avoid catastrophic drift. While Baetodes (Rios-Touma et al. 2011) showed high benthic densi- 
ties in the rapids during the wet season, and this could be related to a higher availability of fast-flow benthos areas for this season. Nectopsyche, showed a clear preference for slow-flow areas in both seasons, possibly because these areas are less exposed and present a smaller risk of being washed away. This preference for slow-velocity areas could be an indicator of a behavioral trait to avoid drift. This has been reported for other crawling caddisflies (Lancaster et al. 2006), which permanently avoid fast-velocity areas. These results are concordant with previous studies regarding the microhabitat preferences of Nectopsyche (Rios-Touma et al. 2011). Nectopsyche has always had greater densities in benthos samples during the dry season and on recolonized stones located in slow-velocity areas during the wet season. Therefore, we may conclude that these taxa are actively searching for refugia in slow-velocity areas. For Baetodes the preference for fast-flowing areas can be interpreted in terms of species traits characteristics. This invertebrate may remain in areas where others are not found due to the water velocity, these areas are more common when the flow is high. Baetodes has the opposite strategy of Nectopsyche. Although the seasonal differences in the abundance of some taxa in temperate streams have been related to the availability of resources or competition (Kohler \& McPeek 1989, Kohler 1992), the strong flow variation in our stream suggests that biotic interactions may play a minor role in community structure.

We found that overall, except for 2 taxa, there was no difference in the invertebrate drift community throughout the day. This was true for all the community metrics tested. This result differs with data from temperate areas (Allan 1984, 1987, Allan et al. 1988) where night drift densities can be up to $10 \times$ greater. However, this is not in agreement with previous studies of tropical streams where diel periodicity in drift was weak or nonexistent (Turcotte \& Harper 1982, Pringle \& Ramirez 1998, Jacobsen \& Bojsen 2002, Rodriguez-Barrios et al. 2007). Despite the overall findings, 2 ephemeropterans, Baetodes and Leptohyphes, showed diel periodicity. This ephemeropteran response may have been elicited by the presence of rainbow trout, reported to be introduced to high Andean rivers (Flecker 1992), and it agrees with studies that have demonstrated that some ephemeroptera larvae in fishless streams did not show diel periodicity in drift; but after contact with fish, they maintained a nocturnal drift behavior even when returned to a fishless habitat (Allan 1978, Allan et al. 1986, Flecker 1992, McIntosh \& Townsend 1994, Peckarsky \& McIntosh 1998, McIntosh et al.
2002). Flecker (1992) found this pattern only for Baetis, and not for Baetodes, in a high Andean stream from Venezuela where trout was introduced, while Turcotte \& Harper (1982) and Jacobsen \& Bojsen (2002) did not find diel periodicity in Baetodes or Baetis in a high Andean stream in Ecuador. We found this pattern for the most abundant ephemeropterans of the stream (which make up a significantly high percentage of the total community density). Our study was time-constrained, and more surveys over several consecutive days in both seasons are needed to better understand the diel periodicity of macroinvertebrate fauna in any stream. We cannot be certain that this pattern always holds in Piburja stream. Unfortunately, the introduced rainbow trout is believed to be widespread among Andean rivers in Ecuador, and it is difficult to find streams without trout to assess the natural condition of fishless Andean streams. From our results, only ephemeropterans seem to exhibit a behavioral response to avoid fish predation in these streams.

The colonization of stones in the tropics is very fast. In the studied stream, there was no difference in the community metrics (richness, density, $H^{\prime}$, Fisher's $\alpha$ ) between Day 7 and Day 25. However, the most common taxa showed clear differences between microhabitats. As a consequence of this, community metrics values were higher for stones located in fast-velocity areas. This has also been reported for stone-fauna experiments in Australia (Downes et al. 1995) and in the high Andean streams of Ecuador (Jacobsen 2005). The degree of stone upturn was only important to a few taxa such as Podonominae and Simuliidae. This can help explain the large values for drift propensity for these taxa during the wet season where the upturning of more stones is expected. Microhabitat played an important role in differentiating communities for both the short-term and midterm colonization experiments. The response of community composition to small-scale environmental changes has been observed in temperate aquatic biota and may be related to both abiotic (e.g. substrates, velocity) and biotic factors (e.g. predator avoidance; Resetarits 1991, 2001, Binckley \& Resetarits 2005). In the present study, there was a general trend for the presence of richer and more diverse invertebrate communities on stones located in rapid areas. This pattern may have resulted from the continuous influence of drift, which is in turn related to the changes in flow, as suggested by the strong correlation we found between flow and drift density. The dynamics on stone fauna at mid-term ( 25 d) varied between seasons, showing a strong influence 
of both drift and the composition of the benthic communities, either in stones located at slow or fastvelocity patches. Only Orthocladiinae was an important component of both the drift and benthos communities in both seasons, while other taxa had different percentages of mean benthos and drift densities according to the season. Differences may be due to the fact that colonizing taxa preferentially came from one source or the other. Thus, Simuliidae showed high drift propensity rates for both seasons and is an important component of drift diversity. As a consequence, colonizing Simuliidae on stones located in the rapids probably came from the drift. In the cases where colonizing taxa were not present in drift, we can assume that they came from nearby benthic patches (e.g. Nectopsyche, Hydrobiosidae). As a result, both sources are important to explaining the composition of the colonizing stones in Piburja stream.

The present study suggests that flow, variability of flow (within and between seasons), and drift response to this variation play a pivotal role in invertebrate colonization and consequently in the structuring of invertebrate communities in different microhabitats of high-altitude tropical streams. The details of the population dynamics need to be better understood, especially for those taxa that present or could present more long-lived aquatic instars or that are fully aquatic. Bridging this gap in our knowledge of the biology of aquatic insects in neotropical areas, especially the Andean areas, is of primary importance in addressing this issue, as well as other ecological questions, and in enhancing the understanding of tropical aquatic ecosystems.

Acknowledgements. We thank the members of the Freshwater Ecology and Management Group of the University of Barcelona, and those of Laboratorio de Ecología Acuática of Universidad San Francisco de Quito for their help and support, which improved the quality of this work. Special thanks to Adelaida Aigaje, Patricio Andino, and Carolina Arroyo for field and lab assistance. This study was financed by the Education for Nature Program of WWF (PhD fellowship grant to B.R.T.), FUCARA Project (AECID-D/ 011294/07), and FCT-Portugal (grant to A.C.E.).

\section{LITERATURE CITED}

> Allan JD (1978) Trout predation and the size composition of stream drift. Limnol Oceanogr 23:1231-1237

Allan JD (1984) The size composition of invertebrate drift in a Rocky Mountain stream. Oikos 43:68-76

Allan J (1987) Macroinvertebrate drift in a Rocky Mountain stream. Hydrobiol 144:261-268

> Allan JD, Russek E (1985) The quantification of stream drift. Can J Fish Aquat Sci 42:210-215

> Allan JD, Flecker AS, McClintock NL (1986) Diel epibenthic activity of mayfly nymphs and its nonconcordance with behavioral drift. Limnol Oceanogr 31:1057-1065

- Allan JD, Herbst GN, Ortal R, Regev Y (1988) Invertebrate drift in the Dan River, Israel. Hydrobiol 160:155-163

Allan JD, Flecker AS, Segnini S, Taphorn DC, Sokol E, Kling GW (2006) Limnology of Andean piedmont rivers of Venezuela. J N Am Benthol Soc 25:66-81

Báez S, Cuesta F, Peralvo M (1999) Caracterización vegetal de la cuenca alta del Río Oyacachi, Reserva Ecológica Cayambe-Coca. EcoCiencia, Quito

Benjamini Y, Hochberg Y (1995) Controlling the false discovery rate: a practical and powerful approach to multiple testing. J R Stat Soc Ser B (Methodological) 57: 289-300

Benson LJ, Pearson RG (1987) The role of drift and effect of season on macroinvertebrate colonization of implanted substrata in a tropical Australian stream. Freshw Biol 18: 109-116

Binckley CA, Resetarits WJ (2005) Habitat selection determines abundance, richness and species composition of beetles in aquatic communities. Biol Lett 1:370-374

Boulton AJ, Spangaro GM, Lake PS (1988) Macroinvertebrate distribution and recolonization on stones subjected to varying degrees of disturbance: an experimental approach. Arch Hydrobiol 113:551-576

Boyero L, Bosch J (2004) Multiscale spatial variation of stone recolonization by macroinvertebrates in a Costa Rican stream. J Trop Ecol 20:85-95

Boyero L, DeLope JL (2002) Short-term recolonization of stones in a tropical island stream. Mar Freshw Res 53: 993-998

Brittain JE, Eikeland TJ (1988) Invertebrate drift: a review. Hydrobiol 166:77-93

Douglas M, Lake PS (1994) Species richness of stream stones: an investigation of the mechanisms generating the species-area relationship. Oikos 69:387-396

> Downes BJ, Lake PS, Schreiber ESG (1995) Habitat structure and invertebrate assemblages on stream stones: a multivariate view from the riffle. Austral Ecol 20:502-514

- Encalada A, Peckarsky B (2006) Selective oviposition of the mayfly Baetis bicaudatus. Oecologia 148:526-537

> Flecker AS (1992) Fish predation and the evolution of invertebrate drift periodicity: evidence from neotropical streams. Ecology 73:438-448

> Flecker AS, Feifarek B (1994) Disturbance and the temporal variability of invertebrate assemblages in two Andean streams. Freshw Biol 31:131-142

> Jacobsen D (2005) Temporally variable macroinvertebratestone relationships in streams. Hydrobiol 544:201-214

Jacobsen D (2008) Tropical high-altitude streams. In: Dudgeon D (ed) Tropical stream ecology. Elsevier/Academic Press, San Diego, CA, p 219-256

Jacobsen D, Bojsen B (2002) Macroinvertebrate drift in Amazon streams in relation to riparian forest cover and fish fauna. Arch Hydrobiol 155:177-197

Kohler SL (1992) Competition and the structure of a benthic stream community. Ecol Monogr 62:165-188

Kohler SL, McPeek MA (1989) Predation risk and the foraging behavior of competing stream insects. Ecology 70 : 1811-1825

Lake PS, Schreiber ESG (1991) Colonization of stones and recovery from disturbance: an experimental study along a river. Verh Internat Verein Limnol 24:2061-2064

Lancaster J, Belyea LR (1997) Nested hierarchies and scaledependence of mechanisms of flow refugium use. J N 
Am Benthol Soc 16:221-238

Lancaster J, Buffin-Belanger T, Reid I, Rice S (2006) Flowand substratum-mediated movement by a stream insect. Freshw Biol 51:1053-1069

Mackay RJ (1992) Colonization by lotic macroinvertebrates: a review of processes and patterns. Can J Fish Aquat Sci 49:617-628

McIntosh AR, Townsend CR (1994) Interpopulation variation in mayfly antipredator tactics: differential effects of contrasting predatory fish. Ecology 75:2078-2090

McIntosh AR, Peckarsky BL, Taylor BW (2002) The influence of predatory fish on mayfly drift: extrapolating from experiments to nature. Freshw Biol 47:1497-1513

Melo AS, Froehlich CG (2004) Colonization by macroinvertebrates of experimentally disturbed stones in three tropical streams differing in size. Int Rev Hydrobiol 89: 317-325

Peckarsky BL, McIntosh AR (1998) Fitness and community consequences of avoiding multiple predators. Oecologia 113:565-576

Pringle CM, Ramirez A (1998) Use of both benthic and drift sampling techniques to assess tropical stream invertebrate communities along an altitudinal gradient, Costa Rica. Freshw Biol 39:359-373

Ramirez A, Pringle CM (2001) Spatial and temporal patterns of invertebrate drift in streams draining a neotropical landscape. Freshw Biol 46:47-62

Resetarits WJ Jr. (1991) Ecological interactions among predators in experimental stream communities. Ecology 72 : 1782-1793

Resetarits W (2001) Colonization under threat of predation: avoidance of fish by an aquatic beetle, Tropisternus lateralis (Coleoptera: Hydrophilidae). Oecologia 129: 155-160

Rios-Touma B (2008) Comunidades de macroinvertebrados en un rio altoandino: importancia del microhabitat, dinamica de la deriva, papel de la materia organica y relevancia de la ovoposicion. $\mathrm{PhD}$ dissertation, Universitat de Barcelona, Spain

Rios-Touma BR, Encalada AC, Prat Fornells N (2009) Leaf litter dynamics and its use by invertebrates in a highaltitude tropical Andean stream. Int Rev Hydrobiol 94: 357-371

Rios-Touma BR, Encalada AC, Prat Fornells N (2011) Macroinvertebrate assemblages of an Andean high altitude tropical stream: the importance of season and flow. Int Rev Hydrobiol 96:667-685

Rodriguez-Barrios J, Ospina-Torres R, Gutierrez JD (2007) Density and biomass of drifting aquatic macroinvertebrates in a tropical mountain creek at Bogotá, Colombia. Caldasia 29:397-412

Skov F (1999) Ambiente físico. In: Pedersen DHB (ed) Oyacachi- La Gente y la Biodiversidad. Centro para la Investigación de la Diversidad Cultural y Biológica de los Bosques Pluviales Andinos (DIVA), Dinamarca y Ediciones Abya Yala, Quito, p 13-14

Smock L (2006) Macroinvertebrate dispersal. In: Hauer FR, Lamberti GA (eds) Methods in stream ecology, 2nd edn. Elsevier/Academic Press, Burlington, MA, p 465-488

Townsend CR, Hildrew AG (1976) Field experiments on the drifting, colonization and continuous redistribution of stream benthos. J Anim Ecol 45:759-772

> Townsend CR, Scarsbrook MR, Doledec S (1997) Quantifying disturbance in streams: alternative measures of disturbance in relation to macroinvertebrate species traits and species richness. J N Am Benthol Soc 16:531-544

> Turcotte P, Harper PP (1982) Drift patterns in a high Andean stream. Hydrobiol 89:141-151

Williams DD, Hynes HBN (1976) Recolonization mechanisms of stream benthos. Oikos 27:265-272 
Appendix 1. Mean values of drift and benthos densities and drift propensity of taxa present at both seasons at Piburja stream, Oyacachi basin, Ecuador

\begin{tabular}{|c|c|c|c|c|c|c|}
\hline \multirow[t]{2}{*}{ Taxa } & \multicolumn{2}{|c|}{ Drift density $\mathrm{m}^{-3}$} & \multicolumn{2}{|c|}{ Benthos density $\mathrm{m}^{-2}$} & \multicolumn{2}{|c|}{ Drift propensity } \\
\hline & Wet & Dry & Wet & Dry & Wet & Dry \\
\hline Heterelmis & 0.014 & 0.004 & 5.952 & 12.245 & 0.002 & 0.000 \\
\hline Total Elmidae & 0.035 & 0.011 & 19.558 & 108.673 & 0.002 & 0.000 \\
\hline Scirtidae gen. A & 0.002 & 0.017 & 1.822 & 5.357 & 0.001 & 0.003 \\
\hline Scirtidae gen. B & 0.011 & - & 2.278 & 1.276 & 0.005 & 0.000 \\
\hline Total Scirtidae & 0.054 & 0.056 & 4.252 & 18.367 & 0.013 & 0.003 \\
\hline Hyalella & 0.009 & 0.004 & 1.701 & 4.082 & 0.005 & 0.001 \\
\hline Ceratopogonidae & 0.065 & 0.146 & 60.374 & 172.959 & 0.001 & 0.001 \\
\hline Chironominae & 0.217 & 0.355 & 103.741 & 147.959 & 0.002 & 0.002 \\
\hline Diamesinae & 0.048 & 0.067 & 0.850 & 57.143 & 0.057 & 0.001 \\
\hline Orthocladiinae & 1.171 & 1.223 & 344.388 & 411.224 & 0.003 & 0.003 \\
\hline Podonominae & 0.258 & 0.005 & 1.701 & 12.755 & 0.152 & 0.000 \\
\hline Tanypodinae & 0.109 & 0.021 & 24.660 & 17.347 & 0.004 & 0.001 \\
\hline Tanytarsini & 0.075 & 0.064 & 21.259 & 68.878 & 0.004 & 0.001 \\
\hline Chelifera & 0.094 & 0.127 & 16.156 & 37.245 & 0.006 & 0.003 \\
\hline Muscidae & 0.062 & 0.002 & 1.367 & 2.296 & 0.045 & 0.001 \\
\hline Maruina & 0.065 & 0.175 & 4.252 & 10.204 & 0.015 & 0.017 \\
\hline Simuliidae & 0.590 & 0.712 & 22.959 & 68.878 & 0.026 & 0.010 \\
\hline Stratiomyidae & 0.092 & 0.161 & 5.102 & 7.143 & 0.018 & 0.023 \\
\hline Tipula & 0.037 & 0.154 & 8.503 & 7.653 & 0.004 & 0.020 \\
\hline Andesiops & 0.007 & 0.020 & 7.653 & 7.143 & 0.001 & 0.003 \\
\hline Baetodes & 1.139 & 0.167 & 121.599 & 41.327 & 0.009 & 0.004 \\
\hline Leptohyphes & 0.034 & 0.005 & 11.905 & 85.714 & 0.003 & 0.000 \\
\hline Planorbiidae & 0.059 & 0.049 & 2.551 & 2.551 & 0.023 & 0.019 \\
\hline Hydracarina & 0.573 & 0.471 & 15.306 & 121.939 & 0.037 & 0.004 \\
\hline Pyralidae & 0.056 & 0.014 & 2.278 & 1.786 & 0.025 & 0.008 \\
\hline Nematomorpha & 0.019 & 0.024 & 2.733 & 5.102 & 0.007 & 0.005 \\
\hline Oligochaeta & 0.045 & 0.128 & 39.966 & 87.245 & 0.001 & 0.001 \\
\hline Gripopterygidae gen. A & 0.017 & 0.031 & 0.850 & 20.833 & 0.020 & 0.001 \\
\hline Claudioperla & 0.007 & - & 8.503 & 14.881 & 0.001 & 0.000 \\
\hline Anacroneuria & 0.001 & - & 0.456 & 0.510 & 0.003 & 0.000 \\
\hline Cochliopsyche & 0.017 & 0.018 & 5.952 & 35.714 & 0.003 & 0.001 \\
\hline Hydrobiosidae & 0.051 & 0.041 & 5.102 & 26.020 & 0.010 & 0.002 \\
\hline Ochrotrichia & 0.297 & 0.250 & 10.204 & 73.980 & 0.029 & 0.003 \\
\hline Nectopsyche & 0.256 & 0.724 & 39.116 & 232.653 & 0.007 & 0.003 \\
\hline Tricladida & - & 0.004 & 1.701 & 11.224 & 0.000 & 0.000 \\
\hline
\end{tabular}


Appendix 2. Summary of Kruskal-Wallis p-values for macroinvertebrate density for season (wet vs. dry), microhabitats (rapids vs slow-flow areas) and colonization days (7 to 25) at Piburja stream. Significant values in bold

\begin{tabular}{|c|c|c|c|c|c|c|c|}
\hline \multirow[b]{2}{*}{ Taxon } & \multicolumn{3}{|c|}{${ }_{-}$Season pooled } & \multicolumn{2}{|c|}{ - Dry season -} & \multicolumn{2}{|c|}{$\ldots$ Wet season } \\
\hline & Season & $\begin{array}{c}\text { Colonization } \\
\text { days }\end{array}$ & Microhabitats & $\begin{array}{c}\text { Colonization } \\
\text { days }\end{array}$ & Microhabitats & $\begin{array}{c}\text { Colonization } \\
\text { days }\end{array}$ & Microhabitats \\
\hline Elmidae & 0.130 & 0.309 & 0.730 & 0.298 & 0.56 & - & - \\
\hline Georissidae & 0.388 & 0.407 & 0.376 & 0.405 & 0.307 & - & - \\
\hline Scirtidae gen. A & 0.388 & 0.407 & 0.376 & 0.405 & 0.307 & - & - \\
\hline Prionocyphon & 0.219 & 0.118 & 0.208 & 0.114 & 0.144 & 0.409 & 0.166 \\
\hline Staphylinidae & 0.247 & 0.407 & 0.376 & 1.000 & 1.000 & 0.409 & 0.470 \\
\hline Hyalella & 0.820 & 0.587 & 0.208 & 0.405 & 0.307 & 0.409 & 0.470 \\
\hline Ostracoda & 0.388 & 0.407 & 0.258 & 0.405 & 0.328 & - & - \\
\hline Blephariceridae & 0.247 & 0.407 & 0.258 & 1.000 & 1.000 & 0.409 & 0.166 \\
\hline Ceratopogonidae & 0.124 & 0.958 & 0.985 & 0.298 & 0.547 & 0.409 & 0.166 \\
\hline Chironominae & 0.001 & 0.438 & 0.033 & 0.095 & 0.324 & 0.530 & 0.047 \\
\hline Diamesinae & 0.018 & 0.160 & 0.118 & 0.134 & 0.223 & - & - \\
\hline Orthocladiinae & 0.008 & 0.072 & 0.172 & 0.006 & 0.112 & 0.013 & 0.375 \\
\hline Podonominae & 0.492 & 0.160 & 0.464 & 0.505 & 0.676 & 0.114 & 0.604 \\
\hline Tanypodinae & 0.000 & 0.756 & 0.043 & 1.000 & 1.000 & 0.672 & 0.002 \\
\hline Tanytarsini & 0.000 & 0.588 & 0.917 & 0.454 & 0.365 & 1.000 & 1.000 \\
\hline Chelifera & 0.437 & 0.705 & 0.027 & 0.251 & 0.043 & 0.815 & 0.162 \\
\hline Limonidae & 0.079 & 0.110 & 0.206 & 0.099 & 0.333 & - & - \\
\hline Clognia & 0.130 & 0.253 & 0.688 & 0.256 & 0.498 & - & - \\
\hline Maruina & 0.219 & 0.587 & 0.847 & 0.581 & 1.000 & - & - \\
\hline Simuliidae & 0.044 & 0.356 & 0.000 & 0.383 & 0.000 & 0.193 & 0.000 \\
\hline Stratiomyidae & 0.219 & 0.545 & 0.208 & 0.545 & 0.144 & - & - \\
\hline Tipula & 1.000 & 0.345 & 1.000 & 1.000 & 1.000 & - & - \\
\hline Andesiops & 0.397 & 0.251 & 0.910 & 0.581 & 0.144 & 0.260 & 0.198 \\
\hline Baetodes & 0.222 & 0.240 & 0.000 & 0.217 & 0.003 & 0.538 & 0.000 \\
\hline Leptohyphes & 0.002 & 0.475 & 0.009 & 0.292 & 0.052 & 0.906 & 0.219 \\
\hline Hydracarina & 0.087 & 0.119 & 0.849 & 0.432 & 0.632 & 0.289 & 0.131 \\
\hline Pyralidae & 0.388 & 0.407 & 0.376 & 0.405 & 0.307 & - & - \\
\hline Nematoda & 0.820 & 0.545 & 0.875 & 0.351 & 0.328 & 0.409 & 0.470 \\
\hline Oligochaeta & 0.615 & 0.196 & 0.627 & 0.700 & 0.974 & 0.048 & 0.571 \\
\hline Gripopterygidae gen. A & 0.645 & 0.446 & 0.909 & 0.502 & 0.976 & 0.086 & 0.958 \\
\hline Claudioperla & 0.388 & 0.407 & 0.258 & 0.405 & 0.328 & - & - \\
\hline Contulma & 0.955 & 0.482 & 0.848 & 0.256 & 0.498 & 0.114 & 0.635 \\
\hline Cochliopsyche & 0.942 & 0.014 & 0.859 & 0.085 & 0.532 & 0.157 & 0.654 \\
\hline Atopsyche & - & - & - & 0.493 & 0.152 & - & - \\
\hline Cailloma & - & - & - & 0.329 & 0.011 & - & - \\
\hline Hydrobiosidae & 0.208 & 0.169 & 0.002 & - & - & 0.277 & 0.198 \\
\hline Smicridea & 0.388 & 0.407 & 0.258 & 0.405 & 0.328 & - & - \\
\hline Ochrotrichia & 0.782 & 0.448 & 0.027 & 0.460 & 0.029 & 0.805 & 0.383 \\
\hline Nectopsyche & 0.221 & 0.095 & 0.486 & 0.251 & 0.674 & 0.250 & 0.151 \\
\hline Tricladida & 0.740 & 0.309 & 0.047 & 0.114 & 0.162 & 0.409 & 0.166 \\
\hline
\end{tabular}

Editorial responsibility: Christine Paetzold, Oldendorf/Luhe, Germany
Submitted: July 15, 2011; Accepted: November 29, 2011

Proofs received from author(s): February 1, 2012 